\title{
Variation of gene effects of six agronomic traits with water regimes in durum wheat
}

\author{
F. Bnejdi ${ }^{1 *}$, M. Saadoun $^{2}$, N. Rassaa ${ }^{3}$ and M. El Gazzah ${ }^{1}$ \\ ${ }^{1}$ Laboratoire de Génétique et Biométrie, Département de Biologie, Faculté des Sciences de Tunis, \\ Université Tunis El Manar 2092, Tunisia. \\ ${ }^{2}$ Laboratoire de Protection des Végétaux, Institut National de la Recherche Agronomique de Tunisie, Tunisia. \\ ${ }^{3}$ Laboratoire de physiologie des céréales, Ecole supérieure d'agriculture du Kef. Tunisie.
}

Accepted 8 May, 2012

\begin{abstract}
This study was carried out to determine the relative importance of additive, dominance and epistatic effects of six agronomic traits evaluated in two crosses under irrigated and rainfed conditions. Separate generations mean analyses revealed that gene effects were dependent upon water regime. Under irrigated regime, only additive and dominance effects were implicated in inheritance of all traits, except plant height in the two crosses and grains per spike in the cross Razzek $\times$ Chili. However, under rainfed condition, additive, dominance and epistasis effects were induced in the genetic control of these traits. Thus, epistasis effect was water regime depended and seems to play a significant role in the genetic adaptability of populations. The variation of inheritance and the presence of genetic interactions complicate the procedure of breeding. Under irrigated regime, selection would be simpler because only additive and dominance effects were implicated in the genetic control of all traits. Consequently, the genetic mechanism would not be stable when plants are grown in environment with lower water availability. However, for the stability of suitable cultivars, selection under rainfed condition (lower water availability) was suggested. The moderate to high narrow-sense heritability estimates for the majority of traits indicate that selection would be efficient.
\end{abstract}

Key words: Durum wheat, epistatic effect, genetic adaptability, heritability, water regime.

\section{INTRODUCTION}

Durum wheat (Triticum durum Desf) is one of the leading cereal crops, in many countries in the world (Maniee et al., 2009; Kahrizi et al., 2010a, b; Mohammadi et al., 2010). In the Mediterranean basin, durum wheat is grown mostly in rainfall areas with different environmental conditions (Edmeades et al., 1989; Loss and Siddique, 1994; Dunkeloh and Jacobeit, 2003). Water deficit is one of the main abiotic stresses that affect production and quality of wheat cultivated in arid and semi-arid regions (Ehdaie and Shakiba, 1996; Plaut et al., 2004; Passioura, 2007; Talebi et al., 2009). In Tunisia, durum covers more than half of the cereal areas (Bnejdi and El Gazzah, 2008),

*Corresponding author. E-mail: fethibnejdi@yahoo.fr. Tel: 0021697531158. where many regions were not exploited due to the wide fluctuation of precipitations and absence of tolerant varieties. To improve crop productivity, it is necessary to understand the mechanism of plant responses to drought stress with the ultimate goal of improving crop performance in the vast areas of the world where rainfall is limiting or unreliable (Huang et al., 2008). Therefore, selection and breeding for drought tolerance has been the main challenge of wheat breeders throughout the last 50 years (Lopez et al., 2003). The choice of an efficient breeding procedure depends to a large extent on knowledge of the genetic system controlling the character to be selected. Generations mean analyses provide information on the relative importance of average effects of the genes (additive effects, dominance deviations and effects due to non allelic genetic interactions) in determining genotypic values of the individuals and, 
Table 1. Means of six morphologic traits $( \pm S E)$ and narrow-sense heritability of parents and offspring populations from two crosses under rainfed condition.

\begin{tabular}{lcccccc}
\hline Population & PH & NHP & SL & SPS & GPS & 100-GW \\
\hline Karim 80 x Inrat 69 & & & & & & \\
$\mathrm{P}_{2}(20) y$ & $96.8 \pm 1.4^{\mathrm{e}}$ & $5.4 \pm 0.6^{\mathrm{a}}$ & $6.0 \pm 0.1^{\mathrm{a}}$ & $19.8 \pm 0.6^{\mathrm{ab}}$ & $49.8 \pm 2.3^{\mathrm{a}}$ & $7.62 \pm 0.7^{\mathrm{a}}$ \\
$\mathrm{BC}_{1} \mathrm{P}_{2}(50)$ & $105.5 \pm 2.4^{\mathrm{c}}$ & $5.2 \pm 0.8^{\mathrm{a}}$ & $3.9 \pm 0.1^{\mathrm{b}}$ & $18.17 \pm 0.4^{\mathrm{b}}$ & $42.0 \pm 2.4^{\mathrm{b}}$ & $7.05 \pm 2.5^{\mathrm{a}}$ \\
$\mathrm{F}_{1}(20)$ & $101.0 \pm 2.5^{\mathrm{d}}$ & $3.3 \pm 0.2^{\mathrm{c}}$ & $6.5 \pm 0.1^{\mathrm{a}}$ & $17.4 \pm 1.0^{\mathrm{b}}$ & $29.1 \pm 1.4^{\mathrm{c}}$ & $4.93 \pm 1.4^{\mathrm{bc}}$ \\
$\mathrm{F}_{2}(100)$ & $89.2 \pm 1.7^{\mathrm{f}}$ & $5.3 \pm 0.2^{\mathrm{a}}$ & $5.3 \pm 0.1^{\mathrm{ab}}$ & $18.1 \pm 0.2^{\mathrm{b}}$ & $48.5 \pm 1.3^{\mathrm{a}}$ & $5.86 \pm 2.3^{\mathrm{b}}$ \\
$\mathrm{BC}_{1} \mathrm{P}_{1}(50)$ & $117.8 \pm 2.6^{\mathrm{a}}$ & $5.7 \pm 0.4^{\mathrm{a}}$ & $2.4 \pm 0.1^{\mathrm{c}}$ & $21.31 \pm 0.5^{\mathrm{a}}$ & $51.5 \pm 1.5^{\mathrm{a}}$ & $5.4 \pm 1.2^{\mathrm{b}}$ \\
$\mathrm{P}_{1}(20)$ & $111.1 \pm 0.9^{\mathrm{b}}$ & $4.8 \pm 0.4^{\mathrm{b}}$ & $5.2 \pm 0.2^{\mathrm{b}}$ & $21.5 \pm 0.4^{\mathrm{a}}$ & $49.7 \pm 2.2^{\mathrm{a}}$ & $4.02 \pm 0.6^{\mathrm{c}}$ \\
$\mathrm{h}^{2}$ & 0.36 & 0.40 & 0.57 & 0.41 & 0.35 & 0.60 \\
& & & & & & \\
$\mathrm{Razzek}_{\mathrm{n}}$ & & & & & & \\
$\mathrm{P}_{2}(20)$ & & & & & \\
$\mathrm{BC}_{1} \mathrm{P}_{2}(50)$ & $93.8 \pm 1.0^{\mathrm{a}}$ & $9.4 \pm 0.7^{\mathrm{a}}$ & $7.2 \pm 0.1^{\mathrm{a}}$ & $17.8 \pm 0.7^{\mathrm{b}}$ & $37.2 \pm 2.6^{\mathrm{b}}$ & $5.34 \pm 0.8^{\mathrm{a}}$ \\
$\mathrm{F}_{1}(20)$ & $90.2 \pm 0.9^{\mathrm{a}}$ & $5.6 \pm 0.4^{\mathrm{b}}$ & $6.97 \pm 0.10^{\mathrm{a}}$ & $15.2 \pm 0.3^{\mathrm{c}}$ & $38.3 \pm 1.6^{\mathrm{b}}$ & $4.75 \pm 0.2^{\mathrm{a}}$ \\
$\mathrm{F}_{2}(100)$ & $100.0 \pm 1.9^{\mathrm{a}}$ & $8.0 \pm 0.9^{\mathrm{a}}$ & $5.7 \pm 0.1^{\mathrm{b}}$ & $16.4 \pm 1.2$ & $37.1 \pm 1.6^{\mathrm{b}}$ & $3.88 \pm 0.9^{\mathrm{bc}}$ \\
$\mathrm{BC}_{1} \mathrm{P}_{1}(50)$ & $79.2 \pm 0.9^{\mathrm{c}}$ & $5.1 \pm 0.3^{\mathrm{b}}$ & $5.57 \pm 0.1^{\mathrm{b}}$ & $14.1 \pm 0.3^{\mathrm{c}}$ & $37.1 \pm 1.1^{\mathrm{b}}$ & $4.01 \pm 1.8^{\mathrm{b}}$ \\
$\mathrm{P}_{1}(20)$ & $84.2 \pm 0.9^{\mathrm{b}}$ & $5.3 \pm 0.4^{\mathrm{b}}$ & $5.96 \pm 0.1^{\mathrm{b}}$ & $20.2 \pm 0.7^{\mathrm{a}}$ & $41.4 \pm 1.3^{\mathrm{a}}$ & $4.09 \pm 0.9^{\mathrm{b}}$ \\
$\mathrm{h}^{2}$ & $80.7 \pm 0.9^{\mathrm{bc}}$ & $7.7 \pm 0.9^{\mathrm{a}}$ & $5.81 \pm 0.1^{\mathrm{b}}$ & $19.4 \pm 0.3^{\mathrm{a}}$ & $41.3 \pm 2.4^{\mathrm{a}}$ & $4.99 \pm 0.8^{\mathrm{a}}$ \\
\hline $\mathrm{F}_{\mathrm{n}}$ & 0.44 & 0.46 & 0.45 & 0.41 & 0.71 & 0.37 \\
\hline
\end{tabular}

For each cross, means within a column bearing different letters differ $(\mathrm{P}<0.05)$. ${ }^{\mathrm{N}}$ Number of plants evaluated in each generation. $\mathrm{PH}$, Plant height; NHP, number of heads per plant; SL, spike length; SPS, spikelets per spike; GW, grain weight.

consequently, mean genotypic values of families and generations (Viana, 2000).

This study was carried out to determine the relative importance of additive, dominance and epistatic effects of six agronomic traits on durum wheat in two crosses under irrigated and rainfed conditions.

\section{MATERIALS AND METHODS}

The study was carried out at Sidi Thabet site under irrigated and rainfed condition (400 ml/year), during the growing season 20092010. The experiment was laid out in randomized complete block design with two replications. Irrigated plots were watered at different growing stages (sowing, tillering, flowering and grain filing). Non-irrigated plots were grown under rainfed condition. Sowing was done in the middle of November in all experiments. Four Tunisian durum wheat genotypes were selected on the basis of their differential yield. Karim 80 and Razzek were known by their excellent productivity $\left(P_{1}\right)$. Inrat 69 and Chili were known by their excellent grain protein content $\left(\mathrm{P}_{2}\right)$. Two crosses were made as follows: Karim $80 \times$ Chili and Razzek $\times$ Inrat $69 . F_{1}$ were selfpollinated to produce $F_{2}$. Backcrosses of $F_{1}$ to each parent were noted as $\mathrm{BC}_{1} \mathrm{P}_{1}$ and $\mathrm{BC}_{1} \mathrm{P}_{2}$, respectively.

Experiments with 12 populations including parental lines $\left(P_{1}\right.$ and $\left.\mathrm{P}_{2}\right), \mathrm{F}_{1}, \mathrm{~F}_{2}$ and backcrosses $\left(\mathrm{BC}_{1} \mathrm{P}_{1}\right.$ and $\left.\mathrm{BC}_{1} \mathrm{P}_{2}\right)$ were grown under irrigated and rainfed conditions in a randomised complete block design with two replications. From each plant, the following data were recorded: plant height $(\mathrm{PH})$ in $\mathrm{cm}$, number of heads per plant (NHP), spike length (SL) in cm, spikelets per spike (SS), number of grains per spike (NGS) and 100-grain weight (100-GW) in g. The number of evaluated plants, equal for each replication was significantly higher in segregating populations (Tables 1 and 2). Prior to analysis, transforming the data by log, square root, arc-sine and arc-sine of square root had no effect on data distribution or in removing epistatic effects. Analyses of variance by population and water regime using SAS software version 6 (SAS Institute, 1990) indicated that the replication and generation $\times$ replication effects were not significant. Therefore, the generations mean analyses were made without adjusting the data for replication.

\section{Gene effects}

Weighted least squares regression analyses were used to solve for mid-parent $(\mathrm{m})$, pooled additive $(\mathrm{d})$, pooled dominance $(\mathrm{h})$ and pooled digenic epistatic ( $\mathrm{i}, \mathrm{I}$ and $\mathrm{j}$ ) genetic effects, following the models and assumptions described in Mather and Jinks (1982). A simple additive-dominance genetic model containing only the $\mathrm{m}, \mathrm{d}$ and $h$ effects was tested first, using the joint scaling test described in Rowe and Alexander (1980). Adequacy of the genetic model was assessed using a chi-square goodness-of-fit statistic derived from deviations from this model. If statistically significant at $p<0.05$, the genetic models containing digenic epistatic effects were then tested until the Chi-square statistic was non-significant.

\section{Heritability}

Homogeneity of variances of non-segregation generations was tested by using Bartlett's test (Bartlett, 1937), and when the variances were heterogeneous, the environmental variance (VE) was replaced by an adequate number of separate parameters and pooled to produce a single environmental variance. Additive, dominance and environmental variance components were estimated using the maximum likelihood method with the observed variance of the six basic generations being used as the initial weights $\left(\mathrm{df} /\left(2 \times \mathrm{S}^{2}\right)\right)$ until the chi-squared test value reached a minimum (Lynch and Walsh, 1998). Narrow-sense heritability was calculated as follows: $h^{2} n=V A /(V A+V D+V E)$; where VA is the 
Table 2. Means of six morphologic traits $( \pm S E)$ assessed in parents and offspring populations from two crosses under irrigated regime.

\begin{tabular}{lcccccc}
\hline Population & PH & NHP & SL & SPS & GPS & $100-G W$ \\
\hline Karim 80 $\times$ Inrat 69 & & & & & & \\
$\mathrm{P}_{2}(20)^{\mathrm{y}}$ & $102.0 \pm 1.0^{\mathrm{b}}$ & $8.0 \pm 0.5^{\mathrm{a}}$ & $6.75 \pm 0.1^{\mathrm{a}}$ & $21.00 \pm 0.3^{\mathrm{a}}$ & $66.50 \pm 2.1^{\mathrm{a}}$ & $6.00 \pm 0.1^{\mathrm{a}}$ \\
$\mathrm{BC}_{1} \mathrm{P}_{2}(50)$ & $117.0 \pm 1.6^{\mathrm{a}}$ & $7.0 \pm 0.3^{\mathrm{a}}$ & $6.43 \pm 0.1^{\mathrm{b}}$ & $22.00 \pm 0.3^{\mathrm{a}}$ & $54.0 \pm 1.6^{\mathrm{b}}$ & $3.90 \pm 0.1^{\mathrm{c}}$ \\
$\mathrm{F}_{1}(20)$ & $109.0 \pm 1.8^{\mathrm{a}}$ & $7.0 \pm 0.1^{\mathrm{a}}$ & $7.13 \pm 0.2^{\mathrm{a}}$ & $20.00 \pm 0.7^{\mathrm{ab}}$ & $62.00 \pm 5.0^{\mathrm{a}}$ & $6.50 \pm 0.1^{\mathrm{a}}$ \\
$\mathrm{F}_{2}(100)$ & $99.0 \pm 1.3^{\mathrm{b}}$ & $4.45 \pm 0.2^{\mathrm{c}}$ & $6.80 \pm 0.1^{\mathrm{a}}$ & $17.00 \pm 0.1^{\mathrm{b}}$ & $45.50 \pm 0.9^{\mathrm{c}}$ & $5.30 \pm 0.1^{\mathrm{b}}$ \\
$\mathrm{BC}_{1} \mathrm{P}_{1}(50)$ & $121.0 \pm 1.1^{\mathrm{a}}$ & $5.0 \pm 0.2^{\mathrm{bc}}$ & $6.30 \pm 0.1^{\mathrm{b}}$ & $24.00 \pm 0.2^{\mathrm{a}}$ & $53.50 \pm 1.1^{\mathrm{b}}$ & $2.40 \pm 0.1^{\mathrm{d}}$ \\
$\mathrm{P}_{1}(20)$ & $112.5 \pm 0.6^{\mathrm{ab}}$ & $5.45 \pm 0.4^{\mathrm{b}}$ & $6.28 \pm 0.1^{\mathrm{b}}$ & $23.00 \pm 0.4^{\mathrm{a}}$ & $56.50 \pm 1.8^{\mathrm{b}}$ & $5.20 \pm 0.1^{\mathrm{b}}$ \\
$\mathrm{h}^{2}{ }_{\mathrm{n}}$ & 0.41 & 0.42 & 0.40 & 0.49 & 0.26 & 0.41 \\
& & & & & & \\
$\mathrm{Razzek}$ Chili & & & & & & \\
$\mathrm{P}_{2}(20)$ & $97.30 \pm 0.9^{\mathrm{a}}$ & $10.0 \pm 0.6^{\mathrm{a}}$ & $7.46 \pm 0.1^{\mathrm{a}}$ & $18.90 \pm 0.2^{\mathrm{a}}$ & $53.00 \pm 2.2^{\mathrm{a}}$ & $5.23 \pm 0.1^{\mathrm{a}}$ \\
$\mathrm{BC}_{1} \mathrm{P}_{2}(50)$ & $90.23 \pm 0.9^{\mathrm{b}}$ & $8.0 \pm 0.4^{\mathrm{b}}$ & $7.23 \pm 0.1^{\mathrm{a}}$ & $18.00 \pm 0.1^{\mathrm{a}}$ & $50.00 \pm 1.6^{\mathrm{a}}$ & $5.00 \pm 0.1^{\mathrm{a}}$ \\
$\mathrm{F}_{1}(20)$ & $100.0 \pm 1.8^{\mathrm{a}}$ & $10.4 \pm 0.5^{\mathrm{a}}$ & $6.00 \pm 0.1^{\mathrm{b}}$ & $17.00 \pm 0.5^{\mathrm{ab}}$ & $40.00 \pm 2.6^{\mathrm{b}}$ & $5.23 \pm 0.1^{\mathrm{a}}$ \\
$\mathrm{F}_{2}(100)$ & $79.23 \pm 0.8^{\mathrm{c}}$ & $5.0 \pm 0.78^{\mathrm{d}}$ & $7.23 \pm 0.1^{\mathrm{a}}$ & $16.89 \pm 0.2^{\mathrm{ab}}$ & $39.09 \pm 1.0^{\mathrm{b}}$ & $4.22 \pm 0.1^{\mathrm{b}}$ \\
$\mathrm{BC}_{1} \mathrm{P}_{1}(50)$ & $84.23 \pm 0.9^{\mathrm{c}}$ & $7.0 \pm 0.3^{\mathrm{bc}}$ & $7.00 \pm 0.1^{\mathrm{ab}}$ & $18.00 \pm 0.1^{\mathrm{ab}}$ & $42.23 \pm 1.6^{\mathrm{b}}$ & $4.89 \pm 0.1^{\mathrm{a}}$ \\
$\mathrm{P}_{1}(20)$ & $80.70 \pm 0.9^{\mathrm{c}}$ & $7.2 \pm 0.9^{\mathrm{c}}$ & $6.93 \pm 0.1^{\mathrm{ab}}$ & $19.00 \pm 0.2^{\mathrm{a}}$ & $44.23 \pm 2.6^{\mathrm{b}}$ & $4.63 \pm 0.2^{\mathrm{ab}}$ \\
$\mathrm{h}^{2}$ & 0.21 & 0.55 & 0.59 & 0.41 & 0.52 & 0.42 \\
\hline
\end{tabular}

For each cross, means within a column bearing different letters differ $(P<0.05)$. ${ }^{Y}$ Number of plants evaluated in each generation. $\mathrm{PH}$, Plant height; NHP, number of heads per plant; SL, spike length; SPS, spikelets per spike; GW, grain weight.

additive genetic component of variance; VD is the dominance genetic component of variance and VE is the environmental variance (Kearsey and Pooni, 1996).

\section{RESULTS}

The mean values and their standard errors for the analyzed traits of the two crosses at irrigated and rainfed condition are presented in Tables 1 and 2. For the four parents, large differences were observed between the majority of traits assessed under irrigated and rainfed conditions. For the majority of genotypes, means of the six traits at irrigated regime were higher than at rainfed condition. Concerning each agronomic trait, the response of genotypes at each condition differed. Under irrigated and rainfed conditions, the highest $\mathrm{PH}$ value was observed for Inrat 69 and the lowest value for Karim 80 . Highest NHP was observed in Karim 80 and Razzek under irrigated regime. SL varied from 2.4 to 7.46 and the highest value was obtained for Chili under rainfall regime. SPS, GPS and 100-GW varied between genotypes and water regime.

Results of separate generations mean analyses are given in Tables 3 and 4 . Under irrigated regime and for the two crosses, the three-parameter model was sufficient to explain the variation in generation means for all traits, except PH in the two crosses and GPS in the cross Razzek $\times$ Chili. Therefore, under rainfed condition, the additive-dominance model failed to explain variation in generation means for all traits and digenic epistatic model was applied and adequately revealed. The additive effect was significant with a negative sign in all cases. The dominance effect was negative in the majority of cases and was significant only in three cases. For all traits, narrow-sense heritability varied between crosses and water regime and ranged from 21 and $71 \%$.

\section{DISCUSSION}

Significant differences were found among the generation means for all the traits which revealed the presence of genetic diversity between cultivars. Generations mean analysis indicated that the mode of gene effects implicated in the control of the majority of traits was depended upon water regime. Our results reveal the implication of epistasis in inheritance of the six agronomic traits under rainfed condition. In contrast, under irrigated regime, epistasis was not implicated in the genetic control of all traits, except PH in the two crosses and GPS in the cross Razzek $\times$ Chili. Recent studies suggest that epistatic effects are implicated in inheritance of quantitative traits in many species, for examples: wheat and Fusarium head blight (Waldron et al., 2008), sesame and powdery mildew (Rao et al., 2011), common bean and Fusarium root rot (Mukankusi et al., 2011) and maize and common smut (Namayandeh et al., 2011). Result of generation mean analysis revealed that inheritance of all traits, except $\mathrm{PH}$ was site dependent. In favourable environment, the plant implores only additive and 
Table 3. Estimates of additive, dominance and epistatic effects $( \pm S E)$ for six agronomic traits in two durum wheat crosses evaluated at irrigated regime.

\begin{tabular}{|c|c|c|c|c|c|c|}
\hline Parameter & PH & NHP & SL & SPS & GPS & 100-GW \\
\hline \multicolumn{7}{|c|}{ Karim $80 \times$ Inrat 69} \\
\hline $\mathrm{m}$ & $28.17 \pm 1.02^{*}$ & $4.09 \pm 0.03^{*}$ & $6.32 \pm 0.02^{*}$ & $21.02 \pm 0.06^{*}$ & $59.54 \pm 0.30^{*}$ & $4.33 \pm 0.01^{*}$ \\
\hline$d$ & $5.09 \pm 0.13^{*}$ & $0.58 \pm 0.04^{*}$ & $0.0 \pm 0.01^{*}$ & $-0.84 \pm 0.05^{\star}$ & $3.87 \pm 0.23^{\star}$ & $0.03 \pm 0.01^{*}$ \\
\hline $\mathrm{h}$ & $202.48 \pm 2.5^{\star}$ & $2.67 \pm 0.05^{*}$ & $0.56 \pm 0.04^{*}$ & $-4.68 \pm 0.12^{*}$ & $21.44 \pm 0.62^{*}$ & $1.05 \pm 0.02^{*}$ \\
\hline i & $79.13 \pm 1.17^{\star}$ & - & - & - & - & - \\
\hline I & $121.6 \pm 1.77^{\star}$ & - & - & - & - & - \\
\hline j & - & - & - & - & - & - \\
\hline$P$ & 0.34 & 0.54 & 0.62 & 0.38 & 0.44 & 0.25 \\
\hline \multicolumn{7}{|c|}{ Razzek × Chili } \\
\hline $\mathrm{m}$ & $1049.61 \pm 0.70^{*}$ & $6.94 \pm 0.09^{*}$ & $7.56 \pm 0.01^{*}$ & $18.83 \pm 0.07^{*}$ & $34.22 \pm 0.60^{*}$ & $4.44 \pm 0.02^{*}$ \\
\hline $\mathrm{h}$ & $-8.30 \pm 0.14^{*}$ & $-0.12 \pm 0.07^{\star}$ & $-0.22 \pm 0.01^{*}$ & $0.04 \pm 0.06$ & $-4.04 \pm 0.38^{*}$ & $-0.1 \pm 0.02^{*}$ \\
\hline $\mathrm{h}$ & $45.92 \pm 1.83^{*}$ & $1.30 \pm 0.16^{\star}$ & $-1.35 \pm 0.02^{*}$ & $-2.37 \pm 0.15^{\star}$ & $10.67 \pm 1.08^{*}$ & $0.64 \pm 0.03^{*}$ \\
\hline $\mathrm{i}$ & $32.23 \pm 0.68^{\star}$ & - & - & - & $16.49 \pm 0.66^{*}$ & - \\
\hline I & $-2.92 \pm 1.39^{*}$ & - & - & - & - & - \\
\hline$J$ & $28.60 \pm 0.56^{*}$ & - & - & - & $23.62 \pm 1.13^{*}$ & - \\
\hline$P$ & - & 0.61 & 0.59 & 0.31 & 0.22 & 0.36 \\
\hline
\end{tabular}

$\mathrm{m}, \mathrm{d}, \mathrm{h}, \mathrm{i}, \mathrm{I}$ and $\mathrm{j}=$ mean, additive, dominance, additive $\times$ additive, dominance $\times$ dominance and additive $\times$ dominance genetic effects, respectively. $\mathrm{P}=$ probability of adequateness of the model; ${ }^{*} \mathrm{p}<0.05$ as compared to zero.

$\mathrm{PH}$, Plant height; NHP, number of heads per plant; SL, spike length; SPS, spikelets per spike; GW, grain weight.

Table 4. Estimates of additive, dominance and epistatic effects ( $\pm S E$ ) for six agronomic traits in two durum wheat crosses evaluated at rainfed condition.

\begin{tabular}{|c|c|c|c|c|c|c|}
\hline Parameter & PH & NHP & SL & SPS & GPS & 100-GW \\
\hline \multicolumn{7}{|c|}{ Karim $80 \times$ Inrat 69} \\
\hline $\mathrm{m}$ & $783.49 \pm 1.62^{*}$ & $4.32 \pm 0.31^{*}$ & $756.16 \pm 0.10^{*}$ & $135.46 \pm 0.27^{*}$ & $364.77 \pm 0.35^{*}$ & $7.29 \pm 0.68^{*}$ \\
\hline$d$ & $17.15 \pm 0.18^{*}$ & $-0.33 \pm 0.07^{\star}$ & $-0.4 \pm 0.01^{*}$ & $0.85 \pm 0.08^{*}$ & $-0.05 \pm 0.35^{\star}$ & $-1.80 \pm 0.10^{*}$ \\
\hline $\mathrm{h}$ & $213.35 \pm 4.39^{*}$ & $4.93 \pm 0.91^{*}$ & $-27.9 \pm 0.24^{*}$ & $12.73 \pm 0.80^{*}$ & $-5.35 \pm 3.60^{*}$ & $-2.21 \pm 0.90 *$ \\
\hline i & $89.8 \pm 1.61^{*}$ & $0.79 \pm 0.29 *$ & $-8.6 \pm 0.10^{*}$ & $6.56 \pm 0.25^{\star}$ & $-7.0 \pm 1.26^{*}$ & $-1.45 \pm 0.69 *$ \\
\hline I & $-126.5 \pm 2.99^{*}$ & $-5.95 \pm 0.60^{*}$ & $20.2 \pm 0.14^{*}$ & $-9.42 \pm 0.67^{*}$ & $-22.3 \pm 2.38^{*}$ & - \\
\hline j & $-38.9 \pm 1.34^{*}$ & - & $3.8 \pm 0.06^{*}$ & $-7.98 \pm 0.28^{*}$ & $-18.9 \pm 1.25^{\star}$ & $5.88 \pm 0.90^{*}$ \\
\hline$P$ & - & 0.27 & - & - & - & 0.45 \\
\hline \multicolumn{7}{|c|}{ Razzek × Chili } \\
\hline $\mathrm{m}$ & $58.0 \pm 0.54^{*}$ & $19.46 \pm 0.29^{*}$ & $5.01 \pm 0.09^{*}$ & $135.50 \pm 0.27^{*}$ & $27.46 \pm 1.05^{\star}$ & $379 \pm 1.05^{\star}$ \\
\hline$d$ & $-6.62 \pm 0.11^{*}$ & $-0.85 \pm 0.13^{\star}$ & $-0.19 \pm 0.01^{*}$ & $0.85 \pm 0.08^{*}$ & $-0.65 \pm 0.27^{\star}$ & $2.05 \pm 0.40^{*}$ \\
\hline $\mathrm{h}$ & $43.18 \pm 0.85^{\star}$ & $-9.05 \pm 0.83^{*}$ & $5.53 \pm 0.26^{\star}$ & $12.85 \pm 0.80^{*}$ & $28.90 \pm 2.85^{*}$ & $26.55 \pm 2.87^{\star}$ \\
\hline $\mathrm{i}$ & - & $1.4 \pm 0.26^{*}$ & $1.98 \pm 0.09^{*}$ & $6.6 \pm 0.26^{*}$ & $12.00 \pm 0.97^{*}$ & $11 \pm 0.97^{\star}$ \\
\hline I & $29.33 \pm 0.55^{\star}$ & $9.9 \pm 0.65^{*}$ & $-4.84 \pm 0.17^{*}$ & $-9.5 \pm 0.67^{*}$ & $-19.27 \pm 1.94^{* *}$ & $-17.7 \pm 1.95^{\star}$ \\
\hline$J$ & $24.89 \pm 0.45^{\star}$ & $2.3 \pm 0.33^{*}$ & - & $-7.9 \pm 0.28^{*}$ & - & $-10.3 \pm 1.1$ \\
\hline $\mathrm{P}$ & 0.56 & - & 0.91 & - & 0.31 & - \\
\hline
\end{tabular}

$\mathrm{m}, \mathrm{d}, \mathrm{h}, \mathrm{i}, \mathrm{I}$ and $\mathrm{j}=$ Mean, additive, dominance, additive $\times$ additive, dominance $\times$ dominance and additive $\times$ dominance genetic effects, respectively. $\mathrm{P}=$ probability of adequateness of the model; ${ }^{*} \mathrm{p}<0.05$ as compared to zero. $\mathrm{PH}$, Plant height; NHP, number of heads per plant; SL, spike length; SPS, spikelets per spike; GW, grain weight.

dominance effects while in unfavourable environment, all mode of gene effects are induced. Epistasis seems to play a significant role in the genetic adaptability of cultivars when cultivated under water deficiency. Similar results were reported for resistance to Septoria tritici in durum wheat (Bnejdi et al., 2011) and resistance to 
Phytophthora nicotianae (Bnejdi et al., 2010, Ceballos et al., 1998) found that epistasis was more pronounced in non-acid than in acid solution for grain yield in maize. Genetic interactions complicate the procedure of fixation of desirable genes in the suitable varieties. Selection under irrigated regime will be efficient and simple to fix the additive genetic effect; however, selection under rainfed condition (lower water availability) could be complicated but more stable. As regards the presence of additive and non-additive gene effects in inheritance of the six traits in the two crosses, the recurrent selection followed by pedigree breeding or a selective diallel mating system may be useful in improving the six agronomic traits in wheat. Under irrigated and rainfed conditions, for the majority of traits, the moderate to high narrow-sense heritability indicated a higher involvement of genetic effects in the expression of these traits and selection is expected to be efficient.

In conclusion, inheritance of the majority of traits varied from simple to complicated depending upon water regime. So, for the cultivars designed for exploitation in a wide range of environmental conditions, selection under unfavourable environment (lower water availability) was recommended for their stability.

\section{REFERENCES}

Bartlett MS (1937). Some examples of statistical methods of research in agriculture and applied biology. J. Roy. Stat. Soc. 4:137-183.

Bnejdi F, El Gazzah M (2008). Inheritance of resistance to yellowberry in durum wheat. Euphytica 163:225-230.

Bnejdi F, Saadoun M, Allagui MB, Colin H, El Gazzah M (2010). Relationship between epistasis and aggressiveness in resistance of pepper (Capsicum annuum L.) to Phytophthora nicotianae. Genet. Mol. Biol. 33:279-284.

Bnejdi F, Saadoun M, El Gazzah M (2011). Genetic adaptability of the inheritance of the resistance to different levels of aggressiveness of Septoria tritici isolates in durum wheat. Crop Prot. 30:1280-1284.

Ceballos H, Pandey S, Narro L, Perez-Velazquez JC (1998). Additive, dominant, and epistatic effects for maize grain yield in acid and nonacid soils. Theory Appl. Genet. 96:662-668.

Dunkeloh A, Jacobeit $\mathrm{J}$ (2003). Circulation dynamics of Mediterranean precipitation variability 1948-1998. Int. J. Climatol. 23:1843-1866.

Edmeades GO, Bolanos J, Lafitte HR, Rajaram S, Pfeiffer WH, Fischer RA (1989). Traditional approaches to breeding for drought resistance in cereals. In: Baker, FWG (ed) Drought Resistance in Cereals. ICSU Press C.A.B International: pp. 27-52.

Ehdaie B, Shakiba MR (1996). Relationship of internode-specific weight and water-soluble carbohydrates in wheat. Cereal Res. Comm. 24:61-67.

Huang RH, Gu L, Chen JL, Huang G (2008). Recent progresses in studies of the temporal-spatial variations of the East Asian monsoon system and their impacts on climate anomalies in China. Chinese $\mathrm{J}$. Atmos. Sci. 32:691-719.
Kahrizi D, Cheghamirza K, Kakaei M, Mohammadi R, Ebadi A (2010a). Heritability and genetic gain of some morpho-physiological variables of durum wheat (Triticum turgidum var. durum.). Afr. J. Biotechnol. 9(30):4687-4691.

Kahrizi D, Maniee M, Mohammadi R, Cheghamirza K (2010b). Estimation of genetic parameters related to morpho-agronomic traits of durum wheat (Triticum turgidum var. durum). Biharean Biol. 4(2):93-97.

Kearsey MJ, Pooni HS (1996). The genetical analysis of quantitative traits. 1st edition. Chapman and Hall, London p. 381.

Lopez CG, Banowetz GM, Peterson CJ, Kronstad WE (2003). Dehydrin expression and drought tolerance in seven wheat cultivars. Crop Sci. 43:577-582.

Loss SP, Siddique KHM (1994). Morphological and physiological traits associated with wheat yield increases in Mediterranean environments. Adv. Agron. 52:229-276.

Lynch M, Walsh B (1998). Genetics and Analysis of Quantitative Traits, Sinauer Associates, Inc, Sunderland. p. 980.

Maniee M, Kahrizi D, Mohammadi R (2009). Genetic Variability of Some Morpho-physiological Traits in Durum Wheat (Triticum turgidum var. durum ) . J. Appl. Sci. 9(7):1383-1387.

Mather K, Jinks JL (1982). Biometrical Genetics. London: Chapman and Hall Ltd, London, p. 396.

Mohammadi R, Armion M, Kahrizi D, Amri A (2010). Efficiency of screening techniques for evaluating durum wheat genotypes under mild drought conditions. Int. J. Plant Prod. 4(1):11-24.

Mukankusi C, Derera J, Melis R (2011). Genetic analysis of resistance to fusarium root rot in common bean. Euphytica, 182: 11-23.

Namayandeh A, Choukan R, Mohahhadi SA, Kamelmanesh MM, Ghasemi S, Hervan EM (2011). Genetic analysis of resistance to common smut in maize (Zea mays L.) using triple test cross. Afr. J. Agric. Res. 6:630-635.

Passioura JB (2007). The drought environment: physical, biological and agricultural perspectives. J. Exp. Bot. 58:113-117.

Plaut Z, Butow BJ, Blumenthal CS, Wrigley CW (2004). Transport of dry matter into developing wheat kernels and its contribution to grain yield under post-anthesis water deficit and elevated temperature. Field Crop. Res. 86:185-198.

Rao PVR, Anuradha G, Prada MJ, Shankar VG, Reddy KR, Reddy NPE, Siddiq EA (2011). Inheritance of powdery mildew tolerance in sesame. Arch. Phyto. Plant Prot. 1:1-9.

Rowe KE, Alexander WL (1980). Computations for estimating the genetic parameter in joint-scaling tests. Crop Sci. 20:109-110.

SAS Institute (1990) SAS/STAT user's guide. Version 6, 4th edn. SAS Institute, Cary.

Talebi R, Fayaz F, Naji AM (2009). Effective selection criteria for assessing drought stress tolerance in durum wheat (Triticum durum Desf.). Gen. Appl. Plant Physiol. 35: 64-74.

Viana JMS (2000). Components of variation of polygenic systems with digenic epistasis. Genet. Mol. Biol. 23:883-892.

Waldron BL, Cai X, Friesen TL, Halley S, Stack RW, Xu SS (2008). Evaluation of fusarium head blight resistance in tetraploid wheat (L.). Crop Sci. 38:805-811. 